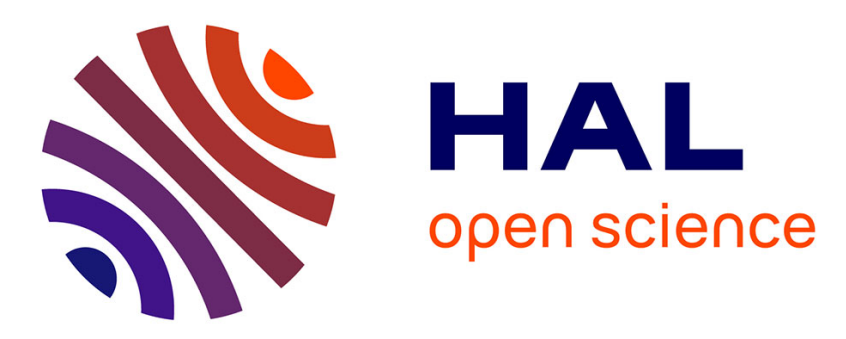

\title{
How teachers' attitudes on GMO relate to their environmental values
}

Jérémy Castéra, Pierre Clément, François Munoz, Franz Bogner

\section{To cite this version:}

Jérémy Castéra, Pierre Clément, François Munoz, Franz Bogner. How teachers' attitudes on GMO relate to their environmental values. Journal of Environmental Psychology, 2018, 57, pp.1-9. 10.1016/j.jenvp.2018.04.002 . hal-01941787

\section{HAL Id: hal-01941787 \\ https://hal.science/hal-01941787}

Submitted on 26 Mar 2020

HAL is a multi-disciplinary open access archive for the deposit and dissemination of scientific research documents, whether they are published or not. The documents may come from teaching and research institutions in France or abroad, or from public or private research centers.
L'archive ouverte pluridisciplinaire HAL, est destinée au dépôt et à la diffusion de documents scientifiques de niveau recherche, publiés ou non, émanant des établissements d'enseignement et de recherche français ou étrangers, des laboratoires publics ou privés. 


\title{
How teachers' attitudes on GMO relate to their environmental values
}

Jérémy Castéra ${ }^{\mathrm{a},{ }^{*}}$, Pierre Clément ${ }^{\mathrm{a}}$, François Munoz ${ }^{\mathrm{b}}$ \& Franz Bogner ${ }^{\mathrm{c}}$

a Aix-Marseille Université, EA4671 ADEF, ENS de Lyon (Aix-Marseille, France)

${ }^{\mathrm{b}}$ Université de Montpellier, UMR AMAP, TA A51/PS2, 34398 Montpellier cedex 5, France

${ }^{\mathrm{c}}$ University of Bayreuth, Centre of Math \& Science Education, NW-1, D-95447 Bayreuth (Germany)

\begin{abstract}
We investigated how teachers' attitudes on GMO in 30 countries relate to two Major Environmental values of Preservation and Utilization. Participating teachers $(\mathrm{N}=10651)$ filled in a questionnaire including items on Preservation- and Utilization-related values (Major Environmental Values, 2-MEV model), and on attitudes to GMO. We analyzed the responses using Exploratory Factor Analysis, and investigated the structure of attitudes based on the multivariate structure. The study confirmed the bi-dimensional nature of the 2-MEV model. The GMO items formed an independent third dimension, although several Pro-GMO attitudes were related to Utilization values. We also found variation of attitudes among countries, plausibly reflecting the influence of different socio-economic and cultural contexts. The results indicate that attitudes and reasoning on sensitive socio-scientific issues such as GMO relate partly to the basic Environmental values of Preservation and Utilization, and partly to pro or anti-GMO attitudes.
\end{abstract}




\section{Key-words:}

GMO, utilization, preservation, attitude, value, teacher

* Corresponding author. Aix-Marseille Université, Laboratoire ADEF, 32 rue Eugène

Cas 13248 Marseille cedex 04, France. E-mail address: jeremy.castera@univ-amu.fr.

\section{Acknowledgements}

We thank all the teachers completing the questionnaire as well as we do for the partners of the involved countries, who coordinated data collection nationally (Algeria: Farida Khammar; Australia: Frances Quinn; Brazil: Graziela Lopez \& Paloma Silva; Burkina Faso: Ivette Béré - Yoda; Cameroon: Lawrence Ntam Nchia; Cyprus: Nicos Valanides; Denmark: Pierre Clément \& Jan Solberg; Estonia: Kai Pata \& Tago Sarapuu; Finland: Anna-Liisa RaumaKosonen; France: Pierre Clément \& Daniel Favre; Gabon: Laurence Ndong; Georgia: Malkhaz Makashvili; Germany: Franz Bogner; Britta Oerke; Hungary: Attila Varga; Italy: Silvia Caravita \& Adriana Valente; Lebanon: Iman Khalil; Lithuania: Jurga Turcinaviciene; Malta: Paul Pace; Morocco: Sabah Selmaoui; Poland: Elwira Samonek-Miciuk; Portugal: Graça Carvalho; Romania: Adrienne Kozan-Naumescu; Senegal: Mame Seyni Thiaw; Serbia: Jelena Stanisavljevic; South Africa: Michele Stears; South-Korea: Hae-Ae Seo; Spain: José María Sanchis; Sweden: Niklas Gericke; Tunisia: Mondher Abrougui; United-Kingdom: Stephen Tomkins). We also thank Michael Wiseman and John Williams for critically commenting the manuscript. Finally, we thank for the financial support of part of the study by the European Commission within the BIOHEAD-Citizen Framework (Specific Targeted Research $n^{\circ}$ 506015, FP6, Priority 7: "Biology, Health and Environmental Education for better Citizenship", 2004-2008). We further thank M-Wiseman for discussing earlier stages of the manuscript. Any opinions, findings, conclusions, or recommendations expressed in this 
material are those of the authors and do not necessarily reflect the views of the European Commission. 


\section{Introduction}

The nature and drivers of public attitudes toward GMO are controversial. Most studies have investigated these attitudes from the viewpoint of consumer perception of risks and benefits (e.g. Bearth \& Siegrist, 2016; Connor \& Siegrist, 2016; Öz, Unsal, \& Movassaghi, 2017; Ruth \& Rumble, 2017; Scott, Inbar, \& Rozin, 2016), but a better understanding should go beyond this focus and consider a broader perspective of environmental values. Much research in environmental psychology has focused on characterizing and understanding the values underlying public environmental concerns, and has built a rich conceptual background (Bogner \& Wilhelm, 1996; Caravita et al., 2008; Dunlap, Liere, Mertig, \& Jones, 2000; Rokeach, 1973; Thompson \& Barton, 1994). We investigated the GMO attitudes of teachers from 30 countries in the context of a model of Major Environmental Values (2-MEV: Bogner \& Wiseman, 2006; Wiseman \& Bogner, 2003). Teachers play a central role in the pupils' and students' citizenship development, and addressing socio-scientific issues (SSI) such as GMO issues in classroom is most challenging (Sadler, Amirshokoohi, Kazempour, \& Allspaw, 2006). It implies developing students' scientific knowledge with regard to pro-environmental attitudes (Meinhold \& Malkus, 2005). Understanding how GMO and environmental teachers' attitudes are connected can help to introduce socio-scientific issues, such as those related to GMO.

\subsection{Socio-scientific issues on GMO}

Socio-scientific issues (SSI) involve both social dilemmas and technological or scientific questions, and are intrinsically controversial (Sadler, 2004). Such controversy makes the introduction of values and ethical dimensions by teachers in classrooms especially 
challenging (Sadler et al., 2006). Genetically Modified Organism (GMO) issues are included in the definition of SSI, and are currently controversial.

Students' decision-making and reasoning are based on skills, knowledge and values (Ratcliffe, 1997). Previous work has shown interactions between scientific knowledge (K), values (V) and social practices (P), particularly when analyzing conceptions related to nature and environment (KVP interaction: Clément, 2010). The values determine a judgment, a set of attitudes or decision-making (Clément, 2012), and the attitudes represent "important predictors of the ways in which people behave”(Cozzarelli, Wilkinson, \& Tagler, 2001). Yap (2014) showed how values related to ethical reasoning can influence decision-making concerning GMO issues, but these values were mainly of a religious nature, with no consideration of the role of environmental values. In the present paper, we investigate the relationship between environmental values (on the basis of the 2-MEV model: Wiseman \& Bogner, 2003) and GMO-related attitudes.

\subsection{Rational and irrational bases of GMO-related attitudes}

There is a great deal of controversy surrounding the issues of GMO within our society, as it is considered potentially dangerous for human/animal health and the environment (Aleksejeva, 2014). Even scientists disagree on the safety of GMO for human health and on their environmental impacts (Hilbeck et al., 2015). Varying knowledge of genetics influences individual attitudes and eating behaviors of consumers (Tas, Balci, Yüksel, \& Sahin Yesilçubuk, 2015; Vecchione, Feldman, \& Wunderlich, 2015; Yang, Ames, \& Berning, 2015). GMO's harm to the environment is considered a major issue (Savadori et al., 2004): $53 \%$ of European citizens think that GMO are harmful to the environment, and 58\% consider them a threat to the safety of future generations (TNS, 2010).

Jurkiewicz, Zagórski, Bujak, Lachowski, and Florek-Łuszczki (2014) showed that a 
sample of young Polish people had little awareness of the potential impact of GMO on human health: although they mentioned potential benefits for the environment, such as reducing the use of mineral fertilizers, herbicides, the dependence of cultivation on weather conditions and climatic changes, and the contamination of the natural environment, they were mainly hostile to the use of GM plants and animals. The authors explain this rejection as an effect of a great "emotional component" rooted within the perception that GMO is unnatural. Tenbült, de Vries, Dreezens, and Martijn (2005) have shown that perceiving GMO as natural or unnatural was central to the acceptance of genetically modified food. Furthermore, the Eurobarometer study indicates that $70 \%$ of Europeans think that "GM food is fundamentally unnatural" (TNS, 2010). The importance of emotions in the acceptance of GMO has also been shown by Sorgo, Jausovec, Jausovec, and Puhek (2012), while Blancke, Van Breusegem, De Jaeger, Braeckman, and Van Montagu (2015) described opposition to GMO as more irrational than rational, and mainly determined by emotions and essentialism, teleological and intentional thinking. Couée (2016) replied to Blancke et al. (2015) and proposed 'a framework of mutual respect and interest between citizens and scientists', defending the potential empirical rationality of GMO opposition. He argued that the European audience (the basis of Blancke et al.'s work) is relatively well informed and educated and the "informative experience of the public on biotechnological issues entails a degree of empirical skepticism that is based on empirical rationality". For instance, $100 \%$ of Argentinian soy is currently a GM plant resistant to glyphosate (Moreira, 2014), theoretically allowing the use of less herbicide (the Roundup Ready produced by Monsanto), yet Argentinian farmers have been forced to use more herbicides, and even new ones, because weeds have mutated. In this case, the use of GM crops has generated more danger for soils and human health, contrary to the initial objective. In another study, Séralini et al. (2014) documented the toxicity on rats of a Roundup herbicide and a Roundup tolerant GM maize, although the results were initially rejected by some other 
scientists.

In addition, the relationships between GMO-related attitudes and environmental concerns have largely been ignored. As the general public have contrasting opinions on the threats or benefits of GMO to the environment (e.g. Jurkiewicz et al., 2014), conceptions and attitudes regarding environmental issues are of paramount importance. Therefore, there is a need to clarify the conceptual relationships of GMO attitudes to the values regarding the use and preservation of natural resources. We investigated GMO attitudes of teachers because all teachers play a key role in environmental education and can influence the attitudes of future citizens. Teachers' conceptions can differ from those of a broader population, because of better knowledge on scientific facts, and are influential in environmental education in any country. We devised a questionnaire to assess the relationship of their attitudes on GMO with their values on the environment.

\subsection{The 2-MEV model}

A major objective in environmental psychology is to characterize and understand environmental worldviews, attitudes and values (J. Liu, Ouyang, \& Miao, 2010; Manoli, Johnson, \& Dunlap, 2007). Basic dimensions underlie the variation of values and individual attitudes toward environment and nature. The pioneering New Environmental Paradigm (NEP: Dunlap et al., 2000; Dunlap \& Van Liere, 1978) characterized environmental concerns along a unidimensional scale, while Thompson and Barton (1994) developed a bi-dimensional framework in which concerns for the environment (ecocentric) and for humans (anthropocentric) form two independent scales. Stern (2000) further suggested a threedimensional framework reflecting egoistic, altruistic and biospheric concerns. Quinn, Castéra, and Clément (2016) defined more precisely anthropocentrism as "human-centeredness conferring intrinsic value mainly to humans", biocentrism as "life-centered in acknowledging the intrinsic value of all living things emphasizing interrelated ecological systems of which 
humans are a part”. Independently, Theys (1993) argued for a bipolar scale (and thus unidimensional) opposing ecocentric and anthropocentric preferences, where altruistic and biospheric poles are merged into ecocentric concern. The 2-MEV (two Major Environmental values) model is based on two independent value-based dimensions representing anthropocentric (Utilization) and ecocentric-biocentric (Preservation) concerns (Bogner \& Wiseman, 1999, 2002b, 2006). According to the 2-MEV model, environmental values regarding (Boeve-de Pauw \& Van Petegem, 2011) Preservation and Utilization form higherorder factors, i.e. they subsume the variation of related attitudes, following the definition of (Rokeach, 1973).

Essential to the 2-MEV is that the dimensions Preservation (P) and Utilization (U) are independent (orthogonal). This means that endorsing $\mathrm{P}$ does not imply rejecting $\mathrm{U}$, whereas endorsing one pole of the NEP does imply rejecting the other (Boeve-de Pauw, 2013). The 2MEV model has thus several advantages: (i) it offers a clear bi-dimensional structure, (ii) it allows inter-study comparisons, and (iii) it fits well with the needs in measuring efforts in Education for Sustainable Development (Boeve-de Pauw \& Van Petegem, 2011). The validity and reliability of the 2-MEV have been repeatedly and independently tested in New Zealand (Milfont \& Duckitt, 2004), the US (Johnson \& Manoli, 2010), Belgium (Boeve-de Pauw \& Van Petegem, 2011) and the Ivory Coast (Borchers et al., 2014).

\subsection{Teachers' conceptions of nature and environment}

We investigated how GMO attitudes of teachers relate to the 2-MEV framework. The 2-MEV model has been supported by several studies on adolescents and teachers (e.g. Bogner \& Wiseman, 2006; Munoz, Bogner, Clément, \& Carvalho, 2009), and proved relevant to assess environmental and earth education programs (Johnson \& Manoli, 2008; Liefländer \& Bogner, 2014). A questionnaire was designed in the BIOHEAD-Citizen project (Carvalho, 
Clément, Bogner, \& Caravita, 2008) to quantify values and attitudes in the context of 2-MEV framework. The first international dataset examined 16 countries (Munoz, Bogner, Clément, et al., 2009), subsequently expanded to 10651 subjects from 30 countries, following the same methodology. Further studies investigated the issue at national level: e.g. Lebanon (Khalil, Clément, \& Laurent, 2007), Poland (Clément, Laurent, \& Samonek, 2011), and more recently Australia (Quinn et al., 2016). The present study is the first to analyze the total dataset from 30 countries.

The objective of our study was to answer three basic questions: (1) Do teachers' conceptions of nature and environment in 30 countries confirm the Preservation $(\mathrm{P})$ and Utilization (U) dimensions of the 2-MEV model? (2) Do their attitudes toward GMO relate to the $\mathrm{U}$ and $\mathrm{P}$ dimensions? (3) Does the structure of values toward the environment and GMO depend on the socio-cultural context of each country?

\section{Material and methods}

2.1. Questionnaire design and sampling scheme

The BIOHEAD-Citizen questionnaire was based on a grid of values related to nature and environment, following Clément (2004) and Forissier and Clément (2003), and included additional questions related to 2-MEV and GMO attitudes. An English version of the questionnaire was translated into each national language. Parallel independent translations were performed and compared, in order to reach a consensus and limit misunderstanding. A test-retest protocol was applied to examine the consistency of answers after one month. In a pilot phase, we used a longer questionnaire in different countries, and selected the items that proved as consistent as possible across countries. We considered here the 2-MEV and GMO- 
related items of the questionnaire (Tables 2, 3 and 4). Answers to each item were coded using a four-point Likert scale (Likert, 1932), from "agree" to "disagree".

The respondents were secondary school teachers of biology and language, and primary school teachers. These three groups were subdivided into two groups of pre-service and inservice teachers, thus forming 6 groups. In each country, the six groups included a minimum of 50 teachers, exceptionally fewer in some countries. The project primarily concerned 18 countries in the context of the BIOHEAD-Citizen project, and was later (2009-2015) extended to include 10651 teachers from 30 countries.

Table 1: Sample sizes in each participating country. The 18 first listed countries (to the dashed line) were included in the initial BIOHEAD-Citizen project.

\begin{tabular}{|c|c|c|}
\hline Countries & Labels used in analyses & Sample size (number of respondents) \\
\hline Algeria & $\mathrm{DZ}$ & 223 \\
\hline Cyprus & $\mathrm{CY}$ & 322 \\
\hline Estonia & $\mathrm{EE}$ & 183 \\
\hline Finland & FI & 306 \\
\hline France & FR & 732 \\
\hline Germany & $\mathrm{DE}$ & 365 \\
\hline Hungary & $\mathrm{HU}$ & 334 \\
\hline Italy & IT & 559 \\
\hline Lebanon & LB & 722 \\
\hline Lithuania & LT & 316 \\
\hline Malta & MT & 198 \\
\hline Morocco & MA & 330 \\
\hline Poland & PL & 316 \\
\hline Portugal & PT & 350 \\
\hline Romania & $\mathrm{RO}$ & 273 \\
\hline Senegal & SN & 324 \\
\hline Tunisia & TU & 753 \\
\hline United-Kingdom & GB & 154 \\
\hline
\end{tabular}




\begin{tabular}{cll} 
Australia & AU & 201 \\
Brazil & BR & 402 \\
Burkina Faso & BF & 296 \\
Cameroon & CM & 523 \\
Denmark & DK & 259 \\
Gabon & GA & 269 \\
Georgia & GE & 296 \\
Serbia & RS & 314 \\
South Africa & ZA & 336 \\
South-Korea & KR & 306 \\
Spain & ES & 318 \\
Sweden & SE & 377 \\
\hline
\end{tabular}

The questionnaire was administered following the same protocol in all countries. Preservice teachers usually completed the questionnaire during a training course, and in-service teachers in their school or during training workshops on topics different from those of our investigation. In all cases, the questionnaire was filled out in the presence of a correspondent researcher in the country, who guaranteed anonymity and collected the forms immediately after completion.

Because sensitive issues related to environmental values and GMO attitudes could depend not only on the national but also on the temporal context, the data were resampled in some of the countries several years after completion of BIOHEAD-Citizen project. The first results, not yet published, showed no change in the conceptions of pre-service teachers of biology, for the topic environment and GMO, from 2006 to 2016, in Morocco and in Algeria, and very limited differences (only for two items) for pre-service Primary Schools teachers in Lebanon, from 2006 to 2014. These partial resampling results suggest that the variation of values and attitudes over time is quite limited in our survey. 
Table 2: Items related to the dimension "Preservation".

\begin{tabular}{ll}
\hline PRE_A1 & We must set aside areas to protect endangered species. \\
\hline PRE_A5 & $\begin{array}{l}\text { If an intensive chicken farm were going to be created near where } \\
\text { you live, you would be against this because it may pollute the } \\
\text { groundwater. }\end{array}$ \\
\hline PRE_A7 & Humans will die out if we don't live in harmony with nature. \\
\hline PRE_A11 & Industrial smoke from chimneys makes me angry. \\
\hline PRE_A22 & I enjoy trips to the countryside. \\
\hline PRE_A28 & $\begin{array}{l}\text { It makes me sad to see the countryside taken over by building } \\
\text { sites. }\end{array}$ \\
\hline PRE_A40 & $\begin{array}{l}\text { It is interesting to know what kinds of animals live in ponds or } \\
\text { rivers. }\end{array}$ \\
\hline PRE_A50 & $\begin{array}{l}\text { All contemporary plant species should be preserved because they } \\
\text { may help in the discovery of new medicines. }\end{array}$ \\
\hline
\end{tabular}

Table 3: Items related to the dimension "Utilization"

\begin{tabular}{ll}
\hline UT_A4 & Nature is always able to restore itself. \\
\hline UT_A16 & Our planet has unlimited natural resources. \\
\hline UT_A17 & $\begin{array}{l}\text { Society will continue to solve even the biggest environmental } \\
\text { problems. }\end{array}$ \\
\hline UT_A18 & Human beings are more important than other living beings. \\
\hline UT_A23 & We need to clear forests to increase agricultural areas. \\
\hline UT_A32 & Humans have the right to change nature as they see fit. \\
\hline UT_A54 & $\begin{array}{l}\text { Only plants and animals of economical importance need to be } \\
\text { protected. }\end{array}$ \\
\hline
\end{tabular}


Table 4: Items related to the attitudes on GMO (Genetically Modified Organisms). Pro_GMO coding refers to an item with positive attitude towards GMO, whereas Anti_GMO refers to negative attitude. K_GMO refers to knowledge about GMO.

\begin{tabular}{ll}
\hline Pro_GMO_A12 & $\begin{array}{l}\text { Genetically modified plants will help to reduce famine in the } \\
\text { world. }\end{array}$ \\
\hline Anti_GMO_A13 & Genetically modified organisms are contrary to nature. \\
\hline Pro_GMO_A39 & $\begin{array}{l}\text { Genetically modified plants are good for the environment because } \\
\text { their cultivation will reduce the use of chemical pesticides (e.g. } \\
\text { insecticides, herbicides). }\end{array}$ \\
\hline Anti_GMO_A47 & $\begin{array}{l}\text { Genetically modified plants are harmful to the environment } \\
\text { because they will contaminate other crop plants, menacing their } \\
\text { survival. }\end{array}$ \\
\hline K_GMO_A49 & $\begin{array}{l}\text { If a person eats genetically modified plants, his/her genes can be } \\
\text { modified. }\end{array}$ \\
\hline
\end{tabular}

\subsection{Statistical analyses}

We hypothesized that the items of Tables 2 to 4 represented basic formative constructs (Bollen \& Lennox, 1991), i.e., their combinations should reflect predominant dimensions of the 2-MEV and GMO attitudes. We performed a hierarchical factor analysis (Carroll, 1993) to determine whether the Preservation (P) and Utilization (U) groups of items formed separable and independent dimensions (research question 1). The analysis is based on a first-order Principal Component Analysis (PCA). We then determined the extent to which GMO attitudes matched the dimensions of the 2-MEV model to those of the higher-order hierarchical factor analysis. We assessed the significance of the relationship between GMO and 2-MEV values by performing Pearson's correlation analyses (research question 2). Furthermore, we analyzed the variation of attitudes among countries along the basic dimensions of the PCA by performing ANOVA analyses of the scores among countries along each axis (research question 3). 
All calculations were performed using the statistical software $\mathrm{R}$ with package ade 4 (Dray \& Dufour, 2007) for Principal Component Analysis, and with package psych for hierarchical factor analysis (Revelle, 2014) .

\section{Results}

\subsection{Relationship of Pro-GMO attitudes to Utilization}

Three basic orthogonal dimensions underlined the attitudes of respondents on 2-MEV and GMO items in Principal Component Analysis (scree-plot: Cattell, 1966, Figure 1). We then performed a Hierarchical Factor Analysis to determine the structure of individual items according to three basic dimensions, plus a general factor $g$ (Carroll, 1993; Jensen \& Weng, 1994). The eigenvalues of the three dimensions were $2.01,1.96$ and 1.69 , respectively, while the general factor had an eigenvalue of 0.48. Therefore, the structure of responses was dominated by the three independent dimensions denoted F1, F2 and F3. The loadings and variance of individual items on these factors are presented in Appendix A and illustrated on Figure 2. 


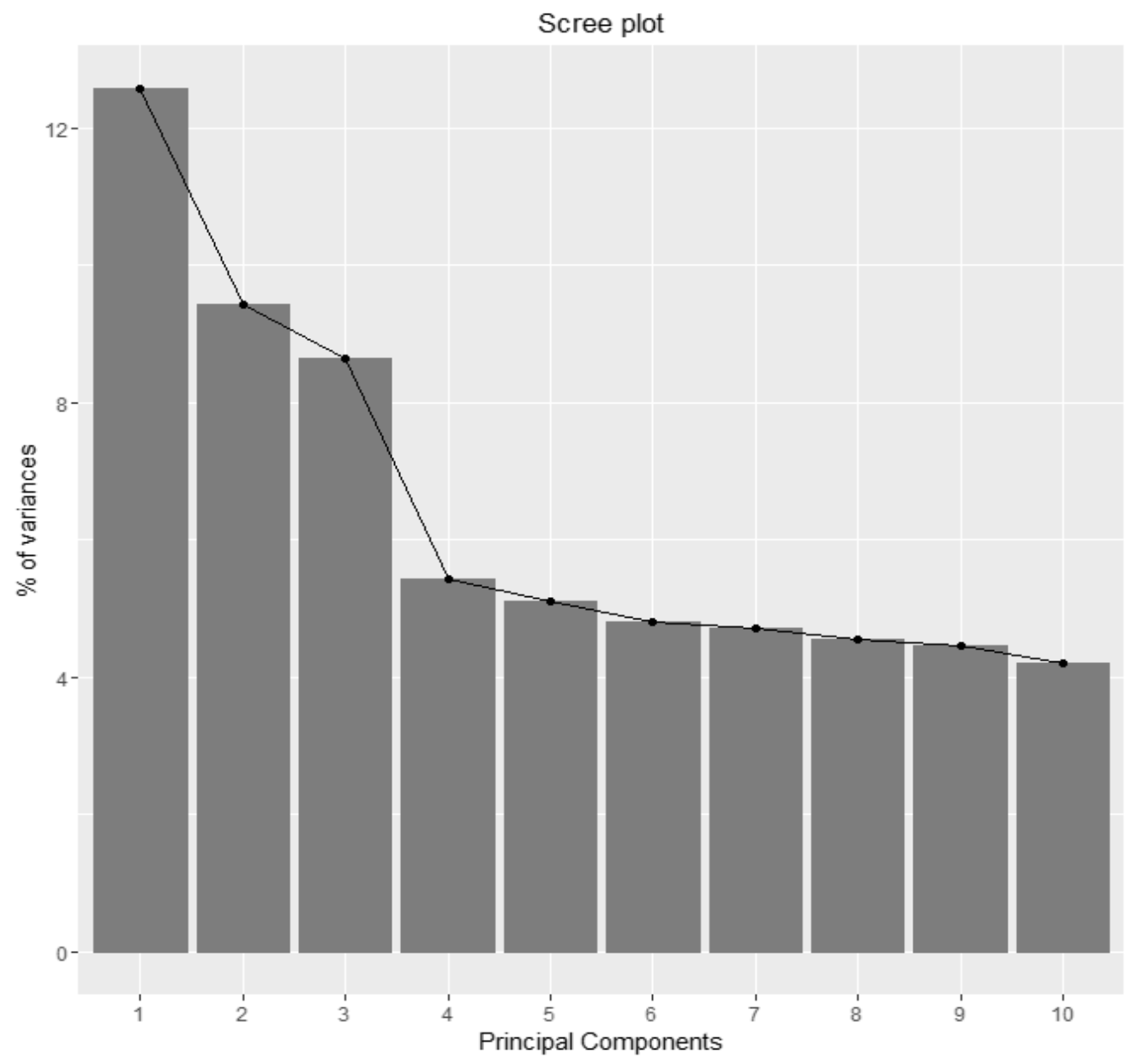

Figure 1: Bar chart of eigenvalues of the Principal Component Analysis. Three components ( $\mathrm{C} 1, \mathrm{C} 2$ and $\mathrm{C} 3)$ are interpretable: the slope of decreasing eigenvalues is steeper between the third and fourth components and does not vary between subsequent components (line). In addition, only the first three components have an eigenvalue appreciably greater than $1(2.52,1.88$ and 1.73 , respectively; subsequent components are below 1.1). Only the ten first components are represented in this graph.

Utilization items were related to F1 (Pearson's $r=0.96$, table 5) and preservation items to F2 (Pearson's $r=0.92$ table 5, and Figure 2), thus confirming the 2-MEV model of environmental values as two orthogonal dimensions. The orthogonality of F1 and F2 imply independence of Utilization and Preservation scores, so that teachers could be both pro- 
utilization and anti-preservation. Nevertheless, some items of the Utilization dimension were negatively related to the Preservation dimension.

Some Pro-GMO and K_GMO items were positively related to the Utilization dimension (Pro_GMO_A39, Pro_GMO_A12 and K_GMO_A49), suggesting linkage of ProGMO attitudes to Utilization values in the 2-MEV model (Pearson's $r=0.43$, Table 5). Conversely, Anti-GMO items were not related to the dimension F2, so that no GMO items was related to Preservation values (Figure 2).

The third factor F3 reflects a contrast with GMO attitudes, with basic opposition of Pro- and Anti-GMO attitudes (Figure 2). Pro and Anti-GMO were correlated in opposite directions on F3 (Pearson's $r=-0.70$ and 0.82 , respectively, table 5). Utilization items did not directly contribute to this factor, although a few Preservation items were weakly related to it (PRE_A7 and PRE_A5). Therefore, F3 represented an additional and independent psychological construct, which indicated that Pro- or Anti-GMO attitudes are partly disconnected from basic environmental values. Although the general factor of the hierarchical analysis ( $g$ in Figure 2) had a low eigenvalue, it contrasted Utilization/Pro-GMO on F1 to Anti-GMO items on F3. It supported the notion that the psychological construct expressed by F3 denotes opposition to the use of GMO. 


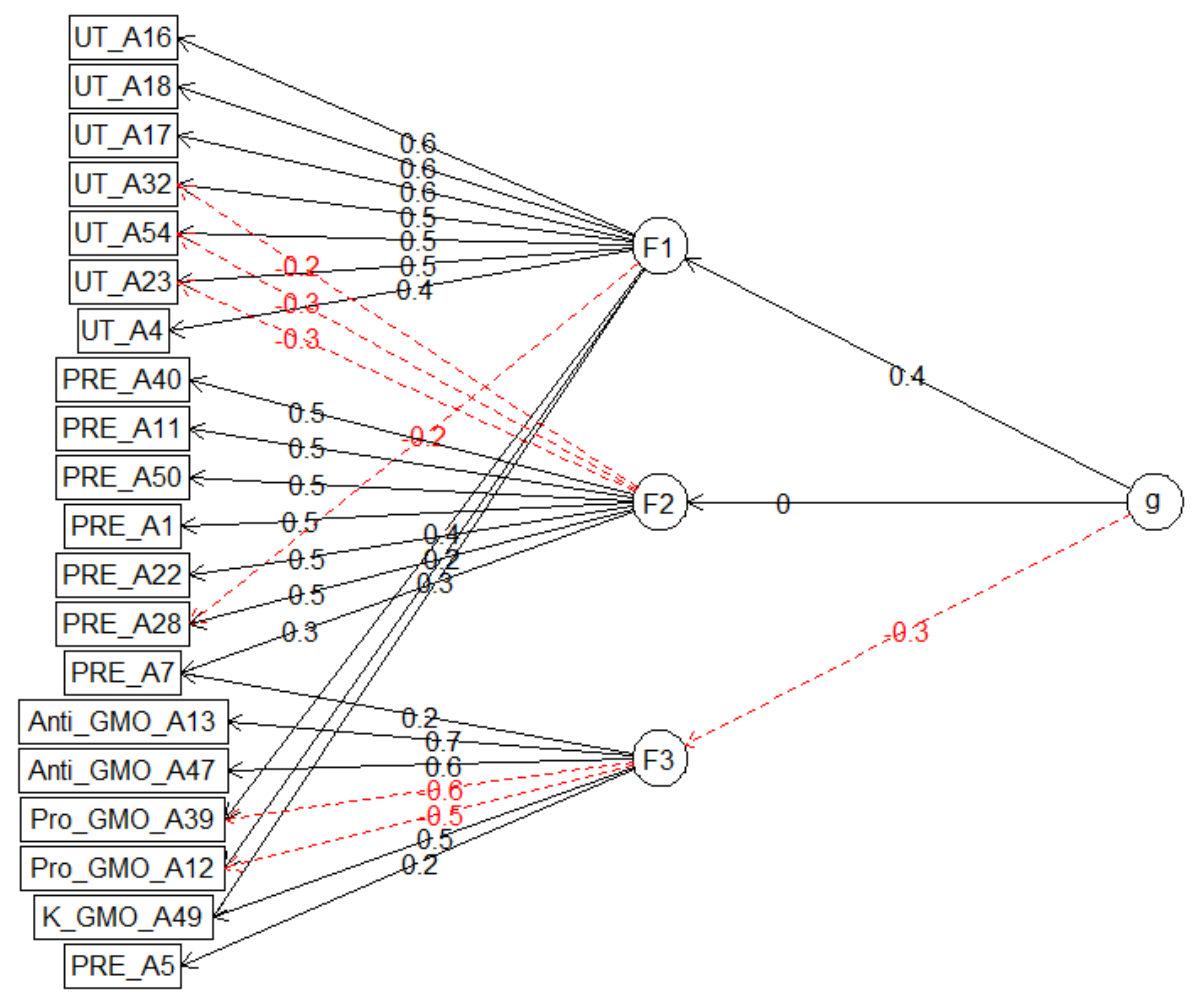

Figure 2: Hierarchical factor analysis for the three sets of items concerning Preservation (PRE), Utilization (UT) and GMO-related attitudes. The analysis yielded three basic orthogonal factors, F1, F2 and F3. The values on the arrows represent the loadings of the items on the factors, with absolute value greater than 0.2 for individual items. The $g$ factor represents a global structure of the items beyond the basic orthogonal factors.

Table 5: Correlations (Pearson) between the mean responses of 10651 teachers to four sets of items (2 items for Pro-GMO, 2 items for Anti-GMO, 7 items for Utilization and 8 items for Preservation) and the factors defined from the Hierarchical Factor Analysis. The highest correlation for each set of items is shown in bold.

Set of items

Utilization
F1

0.96
F2

F3 


$\begin{array}{cccc}\text { Preservation } & -0.07 & \mathbf{0 . 9 2} & 0.23 \\ \text { Pro-GMO } & \mathbf{0 . 4 3} & 0.14 & \mathbf{- 0 . 7 0} \\ \text { Anti-GMO } & -0.02 & 0.19 & \mathbf{0 . 8 2}\end{array}$

3.2. Influence of socio-economic context on environmental values and GMO attitudes

Figure 3 shows how the answers of respondents changed along the three basic factors of Figure 2 among countries. We found difference in scores between countries for the three factors (all ANOVA F-tests $\mathrm{p}<0.001$ ), but the hierarchy was different along the dimensions. Fig. 3 (a) shows that European countries were less utilitarian than African or Asian countries (factor F1), but there was no reverse hierarchy along the Preservation (F2, Fig. 3b), nor along the GMO (F3, Fig. 3c) factors.

(a)

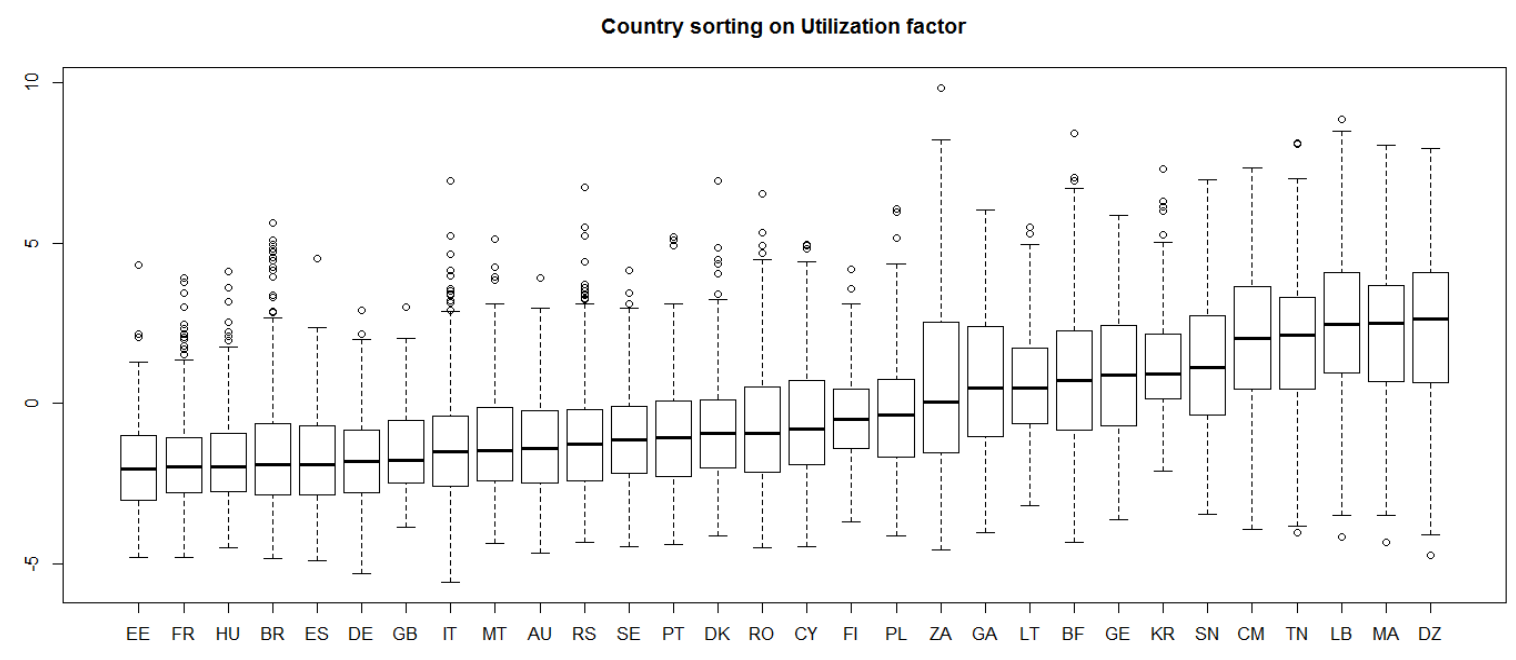

(b) 


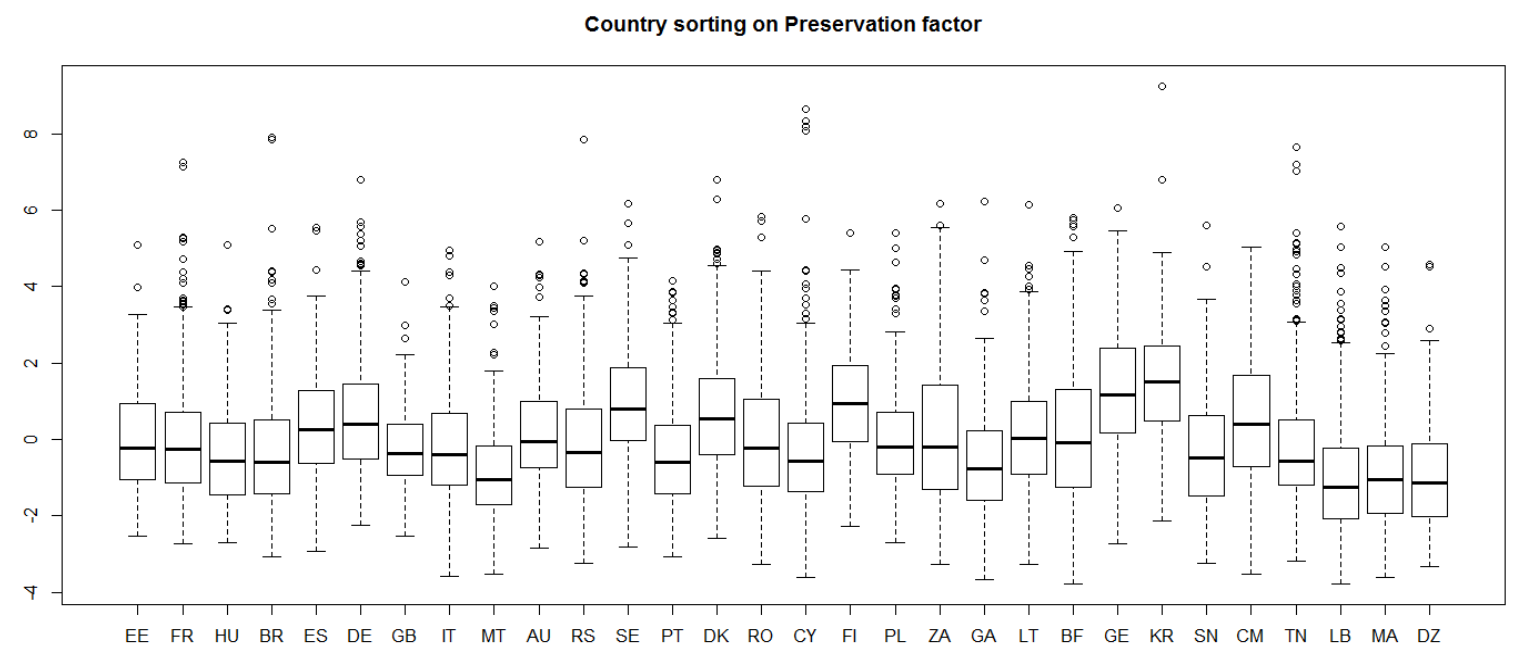

(c)

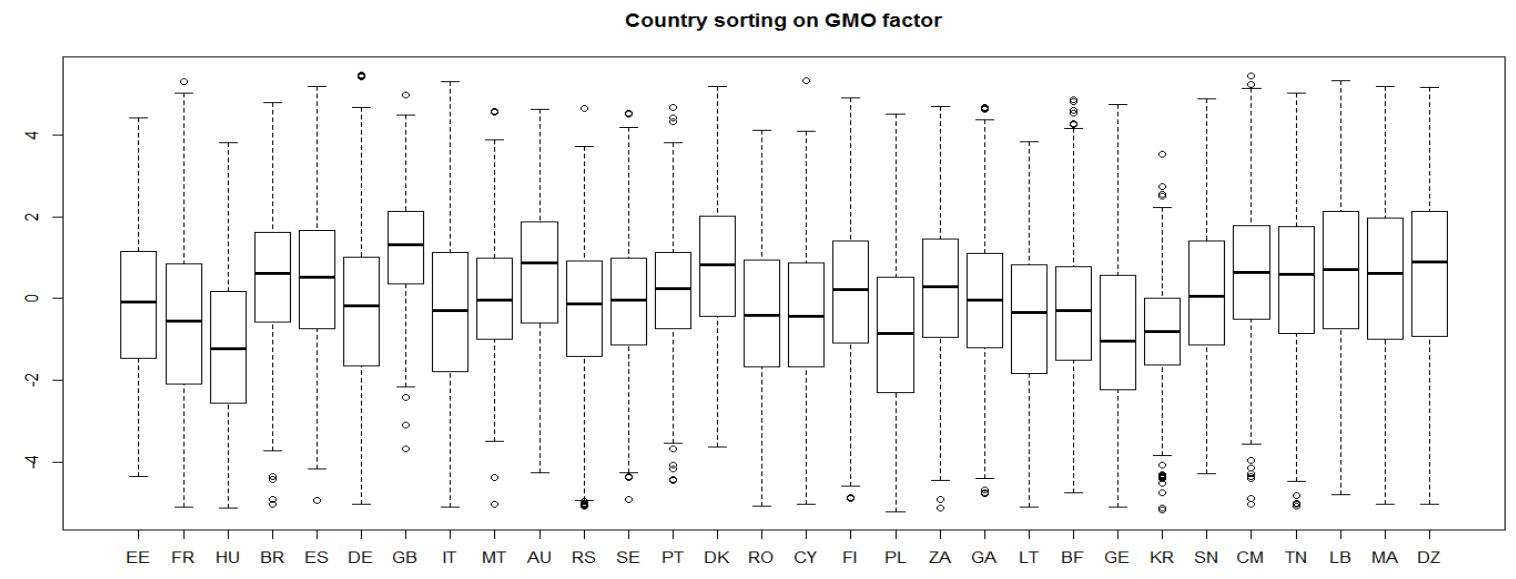

Figure 3: Variation of individual respondent scores among countries, for the three basic orthogonal factors of Figure 2 (F1, F2 and F3, from a to c). ANOVA tests of the score variation among countries were significant in all three cases $(p<0.001)$.

\section{Discussion}

\subsection{Validity of the 2-MEV model worldwide}

The first major result, illustrated by the two factors F1 and F2 (Figure 2 and Table 5), is the validity of 2-MEV in an unprecedented sampling of more than 10000 teachers, across 
30 countries covering all continents. It indicates that values regarding environment and nature are basically and consistently based on two major dimensions representing Utilization and Preservation concerns. The present results support and extend the previous findings of Munoz, Bogner, Clement, and Carvalho (2009), who examined 16 countries, mainly European, to a worldwide perspective (including Australia, Brazil, South Korea, South Africa and West Africa). The validity of 2-MEV was also shown in a longitudinal study of more than 10,000 US students (over a period of 8 years: Bogner, Johnson, Buxner, \& Felix, 2015), and in various bi-national studies in Europe (Bogner, 2000; Bogner \& Wiseman, 1997, 1998, 2002a). In summary, our results could be contingent on the population (teachers) and the sampling scheme considered here, the unprecedented coverage of 30 countries provides an unprecedented and comprehensive perspective on 2-MEV and GMO values worldwide. The robustness and the limits of the 2-MEV dimensions here are remarkable.

However, even though our analyses support the broad independence of the Utilization and Preservation dimensions, we also found some negative correlation between Utilization and Preservation items (Figure 2 and Appendix A). Utilization items are more correlated to F2 (the Preservation dimension) when regarding alteration (UT_23, "clear forests", UT_32, "change nature") or protection of wilderness (UT_54, "only plants and animals of economical importance need to be protected"). It confirmed that some teachers possessed both antiUtilization and pro-Preservation values, or both pro-Utilization and anti-Preservation values. Such a correlation was been repeatedly observed in national analyses in Poland (Clément et al., 2011) and Australia (Quinn et al., 2016), and in some educational intervention studies (Bogner, 1998; Fremerey \& Bogner, 2015; Kossack \& Bogner, 2012; Liefländer \& Bogner, 2016).

4.3 GMO attitudes form an independent psychological construct 
The second major result is that GMO attitudes formed a separate and independent dimension apart from the 2-MEV dimensions (F3, Figure 2). Therefore, attitudes on GMO could not be explained exclusively by referring to Preservation and Utilization dimensions. This result supports the hypothesis that Socio-Scientific Issues (SSI) involve specific ethical and psychological components going beyond the Utilization and Preservation dimensions.

This additional dimension was linked to social practices: political or economical attitudes allowing or forbidding the use of GMO in agriculture or food. It is also largely independent of scientific knowledge, as shown by the answers to the item K_GMO_A49: "If a person eats genetically modified plants, his/her genes can be modified". This assertion is scientifically incorrect. Nevertheless, teachers who did not know the correct answer could still agree with the proposition when they were anti-GMO, as suggested by the loading of the item on factor F3 (Figure 2). The GMO dimension F3 thus represents typical KVP interaction, i.e., the outdated knowledge $(\mathrm{K})$ of the teachers can be related to an Anti-GMO value (V) supporting a struggle (social practice P) against the GMO. It also supports the claim of Blancke et al. (2015) that being against GMO in general remains irrational in light of the scientific evidence, and hence results largely from emotions and intuitions.

Some GMO items were still connected to the Utilization dimension of the 2-MEV model, though none was connected to Preservation values (Figure 2). Apart from their ethical and psychological nature, the GMO attitude thus echoed some concerns related to the Utilization of environmental resources. The development of GMO for agriculture is based on the objectives of sustainable food production and exploitation of natural resources, which by nature pertain to the Utilization dimension (Bogner \& Wiseman, 2006). In addition, much of the scientific debate on GMO concerns the benefits and costs of using GMO, e.g., Blancke et al. (2015) supported the Utilization of GMO, while Couée (2016), Moreira (2014) or Séralini et al. (2014) pointed to adverse effects for the environment and human health. Conversely, the 
debate on GMOs has less emphasized the effects of GMO on biodiversity, although it has been shown that gene flow from GMO crops to weeds can affect native biodiversity (e.g. Chen, Lee, Song, Suh, \& Lu, 2004). Lack of correlation of GMO attitudes to the Preservation dimension thus indicates that most public concern focuses on the way GMO issues such as for instance environmental resource management, food safety, and human health. An open question is whether increasing awareness on the consequences for biodiversity could alter the correlation of GMO attitudes to Preservation.

\subsection{Utilization, Preservation and GMO values vary across countries}

The third major result regards the substantial variation of 2-MEV and GMO attitudes across countries (Figure 3). This variation could reflect the influence of social, economical and political contexts. The ranking of countries related to utilitarian values (Figure 3a) did not correspond to their ranking related to pro-GMO positions (Figure 3c). For instance, African and Middle-East countries, although having the highest scores on Utilization, possibly reflecting lower economic development, were not the most pro-GMO. And some developed countries with low scores on utilitarian values were clearly pro-GMO (such as Great Britain or Australia). Therefore, the relative importance of the three basic 2-MEV and GMO dimensions varied across countries, depending on the respective socio-cultural contexts.

\subsection{Lessons for education and citizenship}

The work of S.-C. Liu and Lin (2015) on undergraduate students tends to support the idea that knowledge in genetic engineering and the level of university training impact negatively attitudes to GMO products. A major aim of environmental education is favoring sustainable life-styles by promoting less utilitarian values, as suggested by Bogner (2002). Considering the lack of consensus regarding GMO safety for human health and environment, 
even among scientists, it is reasonable, as a precaution, to promote less utilitarian values and discourage strict Pro-GMO attitudes. Promoting more Preservation and fewer Utilization values at school and in teacher training is probably not the only solution, however. Providing basic knowledge on biotechnologies is also needed to train informed and active citizens, and could foster more constructive debates on the political and scientific scene. In this way, the perception of GMO should be not only value-based but knowledge-based as well. 


\section{References}

Aleksejeva, I. (2014). EU Experts' Attitude Towards Use of GMO in Food and Feed and Other Industries. Procedia-Social and Behavioral Sciences, 110, 494-501.

Bearth, A., \& Siegrist, M. (2016). Are risk or benefit perceptions more important for public acceptance of innovative food technologies: A meta-analysis. Trends in Food Science \& Technology, 49, 14-23.

Blancke, S., Van Breusegem, F., De Jaeger, G., Braeckman, J., \& Van Montagu, M. (2015). Fatal attraction: the intuitive appeal of GMO opposition. Trends in Plant Science, 20(7), 414-418. doi:http://dx.doi.org/10.1016/j.tplants.2015.03.011

Boeve-de Pauw, J. (2013). Valuing the invaluable: effects of individual, school and cultural factors on the environmental values of children. Environmental Education Research, 19(2), 249-250. doi:10.1080/13504622.2012.700700

Boeve- de Pauw, J., \& Van Petegem, P. (2011). The effect of Flemish eco- schools on studentenvironmental knowledge, attitudes, and affect. International Journal of Science Education, 33(11), 1513-1538.

Bogner, F. X. (1998). Environmental Perception of Irish and Bavarian Adolescents. A Comparative Empirical Study. Environmentalist, 18, 27-38.

Bogner, F. X. (2000). Adolescent Environmental Perception of Italian and Five European Non-Mediterranean Pupil Populations. Fresenius Environmental Bulletin, 9, 570-581.

Bogner, F. X. (2002). The influence of a residential outdoor education programme to pupil's environmental perception. European journal of Psychology of Education, 17(1), 1934.

Bogner, F. X., Johnson, B., Buxner, S., \& Felix, L. (2015). The 2-MEV model: Constancy of adolescent environmental values within an 8-year time frame. International Journal of Science Education, 37(12), 1938-1952. 
Bogner, F. X., \& Wilhelm, M. G. (1996). Environmental perspectives of pupils: the development of an attitude and behaviour scale. Environmentalist, 16(2), 95-110.

Bogner, F. X., \& Wiseman, M. (1997). Environmental perspectives of Danish and Bavarian pupils: towards a methodological framework. Scandinavian Journal of Educational Research, 41(1), 53-71.

Bogner, F. X., \& Wiseman, M. (1998). Environmental perception of Swiss and Bavarian pupils: an empirical evaluation. Schweizerische Zeitschrift für Soziologie, 24(3), 547566.

Bogner, F. X., \& Wiseman, M. (1999). Toward Measuring Adolescent Environmental Perception. European Psychologist, 4(3), 139-151. doi:10.1027//1016-9040.4.3.139

Bogner, F. X., \& Wiseman, M. (2002a). Environmental perception of French and some Western European secondary school students. European journal of Psychology of Education, 17(1), 3-18.

Bogner, F. X., \& Wiseman, M. (2002b). Environmental perception: Factor profiles of extreme groups. European Psychologist, 7(3), 225.

Bogner, F. X., \& Wiseman, M. (2006). Adolescents' attitudes towards nature and environment: Quantifying the 2-MEV model. Environmentalist, 26(4), 247-254.

Bollen, K., \& Lennox, R. (1991). Conventional wisdom on measurement: A structural equation perspective. Psychological bulletin, 110(2), 305.

Borchers, C., Boesch, C., Riedel, J., Guilahoux, H., Ouattara, D., \& Randler, C. (2014). Environmental education in Cote d'Ivoire/West Africa: Extra-curricular primary school teaching shows positive impact on environmental knowledge and attitudes. International Journal of Science Education, Part B, 4(3), 240-259. 
Caravita, S., Valente, A., Luzi, D., Pace, P., Valanides, N., Khalil, I., . . Clement, P. (2008). Construction and Validation of Textbook Analysis Grids for Ecology and Environmental Education. Science Education International, 19(2), 97-116.

Carroll, J. B. (1993). Human cognitive abilities: A survey of factor-analytic studies. Cambridge: Cambridge University Press.

Carvalho, G., Clément, P., Bogner, F., \& Caravita, S. (2008). BIOHEAD-Citizen: Biology, Health and Environmental Education for better Citizenship, Final Report. (FP6, Priority 7, Project N CITC-CT-2004-506015). Brussels: European Community Retrieved from http://cordis.europa.eu/documents/documentlibrary/124856931EN6.pdf.

Cattell, R. B. (1966). The scree test for the number of factors. Multivariate behavioral research, 1(2), 245-276.

Chen, L. J., Lee, D. S., Song, Z. P., Suh, H. S., \& Lu, B.-R. (2004). Gene flow from cultivated rice (Oryza sativa) to its weedy and wild relatives. Annals of botany, 93(1), 67-73.

Clément, P. (2004). Construction des umwelts et philosophies de la nature. In J. M. Exbrayat \& P. Moreau (Eds.), L’homme méditerranéen et son environnement (pp. 93-106). Lyon: Société Linéenne Lyon.

Clément, P. (2010). Conceptions, représentations sociales et modèle KVP. Skholê, 16, 55-70.

Clément, P. (2012). Values in science and in science education. Journal INEDP, 1(1), 26.

Clément, P., Laurent, C., \& Samonek, E. (2011). Polish teachers' conceptions related to environment. Annales Universitatis Paedagogicae Cracoviensis, Studia ad Didacticam Biologiae Pertinentia I, 86, 104-115.

Connor, M., \& Siegrist, M. (2016). The stability of risk and benefit perceptions: a longitudinal study assessing the perception of biotechnology. Journal of Risk Research, 19(4), 461475. 
Couée, I. (2016). Hidden Attraction: Empirical Rationality in GMO Opposition. Trends in Plant Science, 21(2), 91. doi:10.1016/j.tplants.2015.12.002

Cozzarelli, C., Wilkinson, A. V., \& Tagler, M. J. (2001). Attitudes Toward the Poor and Attributions for Poverty. Journal of social issues, 57(2), 207-227. doi:10.1111/00224537.00209

Dray, S., \& Dufour, A.-B. (2007). The ade4 package: implementing the duality diagram for ecologists. Journal of statistical software, 22(4), 1-20.

Dunlap, R. E., Liere, K., Mertig, A., \& Jones, R. E. (2000). Measuring endorsement of the new ecological paradigm: A revised NEP scale. Journal of social issues, 56(3), 425442.

Dunlap, R. E., \& Van Liere, K. D. (1978). The "new environmental paradigm". The Journal of Environmental Education, 9(4), 10-19.

Forissier, T., \& Clément, P. (2003). Les systèmes de valeurs d'enseignants du Secondaire sur la nature et sur l'environnement. Une analyse comparative en France, Allemagne et Portugal. In A. Giordan, J.-L. Martinand, \& D. Raichvarg (Eds.), Ignorances et questionnements, Actes des XXVes Journées internationales sur la communication, l'éducation et la culture scientifiques et industrielles (pp. 1-6). Paris: DIRES.

Fremerey, C., \& Bogner, F. X. (2015). Cognitive learning in authentic environments in relation to green attitude preferences. Studies in Educational Evaluation, 44, 9-15.

Hilbeck, A., Binimelis, R., Defarge, N., Steinbrecher, R., Székács, A., Wickson, F., .. . Hansen11, M. (2015). No scientific consensus on GMO safety. Environmental Sciences Europe, 27(1), 4.

Jensen, A. R., \& Weng, L.-J. (1994). What is a good g? Intelligence, 18(3), 231-258. 
Johnson, B., \& Manoli, C. C. (2008). Using Bogner and Wiseman's model of ecological values to measure the impact of an earth education programme on children's environmental perceptions. Environmental Education Research, 14(2), 115-127.

Johnson, B., \& Manoli, C. C. (2010). The 2-MEV scale in the United States: a measure of children's environmental attitudes based on the theory of ecological attitude. The Journal of Environmental Education, 42(2), 84-97.

Jurkiewicz, A., Zagórski, J., Bujak, F., Lachowski, S., \& Florek-Łuszczki, M. (2014). Emotional attitudes of young people completing secondary schools towards genetic modification of organisms (GMO) and genetically modified foods (GMF). Annals of agricultural and environmental medicine: AAEM, 21(1), 205-211.

Khalil, I., Clément, P., \& Laurent, C. (2007). Anthropocentrées, écolocentrées ou sentimentocentrées: Les conceptions d'enseignants et futurs enseignants libanais sur la nature et l'environnement. Feuilles Libanaises (Ligue des Professeurs de l'Université Libanaise), 29, 67-92.

Kossack, A., \& Bogner, F. X. (2012). How does a one-day environmental education programme support individual connectedness with nature? Journal of Biological Education, 46(3), 180-187.

Liefländer, A. K., \& Bogner, F. X. (2014). The effects of children's age and sex on acquiring pro-environmental attitudes through environmental education. The Journal of Environmental Education, 45(2), 105-117.

Liefländer, A. K., \& Bogner, F. X. (2016). Educational impact on the relationship of environmental knowledge and attitudes. Environmental Education Research, 1-14. doi:10.1080/13504622.2016.1188265

Likert, R. (1932). A technique for the measurement of attitudes. Archives of psychology, 140(5), 1-55. 
Liu, J., Ouyang, Z., \& Miao, H. (2010). Environmental attitudes of stakeholders and their perceptions regarding protected area-community conflicts: A case study in China. Journal of environmental management, 91(11), 2254-2262.

Liu, S.-C., \& Lin, H.-S. (2015). Exploring Undergraduate Students' Mental Models of the Environment: Are They Related to Environmental Affect and Behavior? The Journal of Environmental Education, 46(1), 23-40.

Manoli, C. C., Johnson, B., \& Dunlap, R. E. (2007). Assessing children's environmental worldviews: Modifying and validating the New Ecological Paradigm Scale for use with children. The Journal of Environmental Education, 38(4), 3-13.

Meinhold, J. L., \& Malkus, A. J. (2005). Adolescent environmental behaviors: Can knowledge, attitudes, and self-efficacy make a difference? Environment and behavior, $37(4), 511-532$.

Milfont, T. L., \& Duckitt, J. (2004). The structure of environmental attitudes: A first-and second-order confirmatory factor analysis. Journal of Environmental Psychology, 24(3), 289-303.

Moreira, P. (2014, 29 August 2014). OGM et pesticides: le désastre argentin, la guerre transatlantique. Médiapart, p. 4. Retrieved from https://www.mediapart.fr/journal/economie/290814/ogm-et-pesticides-le-desastre$\underline{\text { argentin-la-guerre-transatlantique?onglet=full }}$

Munoz, F., Bogner, F., Clement, P., \& Carvalho, G. S. (2009). Teachers' conceptions of nature and environment in 16 countries. Journal of Environmental Psychology, 29(4), 407-413.

Munoz, F., Bogner, F., Clément, P., \& Carvalho, G. S. (2009). Teachers' conceptions of nature and environment in 16 countries. Journal of Environmental Psychology, 29(4), 407-413. 
Öz, B., Unsal, F., \& Movassaghi, H. (2017). Consumer attitudes toward genetically modified food in the United States: Are Millennials different? Journal of Transnational Management, 1-19.

Quinn, F., Castéra, J., \& Clément, P. (2016). Teachers' conceptions of the environment: anthropocentrism, non-anthropocentrism, anthropomorphism and the place of nature. Environmental Education Research, 22(6), 893-917. doi:10.1080/13504622.2015.1076767

Ratcliffe, M. (1997). Pupil decision- making about socio- scientific issues within the science curriculum. International Journal of Science Education, 19(2), 167-182.

Revelle, W. (2014). psych: Procedures for psychological, psychometric, and personality research. Northwestern University, Evanston, Illinois, 165.

Rokeach, M. (1973). The nature of human values. New York: Free press.

Ruth, T. K., \& Rumble, J. N. (2017). What's in a Name? The Influence of Persuasive Communication on Florida Consumers’ Attitude toward Genetically Modified Food. Journal of Applied Communications, 101(2), 7.

Sadler, T. D. (2004). Informal reasoning regarding socioscientific issues: A critical review of research. Journal of research in science teaching, 41(5), 513-536.

Sadler, T. D., Amirshokoohi, A., Kazempour, M., \& Allspaw, K. M. (2006). Socioscience and ethics in science classrooms: Teacher perspectives and strategies. Journal of research in science teaching, 43(4), 353-376.

Savadori, L., Savio, S., Nicotra, E., Rumiati, R., Finucane, M., \& Slovic, P. (2004). Expert and public perception of risk from biotechnology. Risk Analysis, 24(5), 1289-1299.

Scott, S. E., Inbar, Y., \& Rozin, P. (2016). Evidence for absolute moral opposition to genetically modified food in the United States. Perspectives on Psychological Science, 11(3), 315-324. 
Séralini, G.-E., Clair, E., Mesnage, R., Gress, S., Defarge, N., Malatesta, M., . . . de Vendômois, J. S. (2014). Republished study: long-term toxicity of a Roundup herbicide and a Roundup-tolerantgenetically modified maize. Environmental Sciences Europe, 26(1), 14. doi:10.1186/s12302-014-0014-5

Sorgo, A., Jausovec, N., Jausovec, K., \& Puhek, M. (2012). The influence of intelligence and emotions on the acceptability of genetically modified organisms. Electronic Journal of Biotechnology, 15(1), 1-11.

Stern, P. (2000). Toward a coherent theory of environmentally significant behavior. Journal of social issues, 56(3), 407-424.

Tas, M., Balci, M., Yüksel, A., \& Sahin Yesilçubuk, N. (2015). Consumer awareness, perception and attitudes towards genetically modified foods in Turkey. British Food Journal, 117(5), 1426-1439.

Tenbült, P., de Vries, N. K., Dreezens, E., \& Martijn, C. (2005). Perceived naturalness and acceptance of genetically modified food. Appetite, 45(1), 47-50.

Theys, J. (1993). L'environnement à la recherche d'une définition (Vol. 1). Paris: Institut français de l'environnement.

Thompson, S. C. G., \& Barton, M. A. (1994). Ecocentric and anthropocentric attitudes toward the environment. Journal of Environmental Psychology, 14(2), 149-157.

TNS. (2010). Eurobarometer 73.1: The European Parliament, Biotechnology, and Science and Technology, January-February 2010. Retrieved from http://doi.org/10.3886/ICPSR31483.v1

Vecchione, M., Feldman, C., \& Wunderlich, S. (2015). Consumer knowledge and attitudes about genetically modified food products and labelling policy. International journal of food sciences and nutrition, 66(3), 329-335. 
Wiseman, M., \& Bogner, F. X. (2003). A higher-order model of ecological values and its relationship to personality. Personality and Individual Differences, 34(5), 783-794. doi:http://dx.doi.org/10.1016/S0191-8869(02)00071-5

Yang, T., Ames, G., \& Berning, J. (2015). Determinants of Consumer Attitudes and Purchasing Behaviors on Genetically Modified Foods in Taiwan. Journal of Food Distribution Research, 46(1), 30-36.

Yap, S. F. (2014). Beliefs, values, ethics and moral reasoning in socio-scientific education. Issues in Educational Research, 24(3), 299-319. 


\section{Appendix A: Item loadings on the factors of the Hierarchical Factor Analysis}

The table below includes the loadings of individual items on the three first-order orthogonal factors, F1, F2 and F3, and on the second-order general factor, g. The loadings in italic are between 0.2 and 0.4 in absolute value; the loading in bold are greater than 0.4 in absolute value. The variables with the appended minus sign (-) were reversely coded.

The table also includes the percent of general factor variance in the common variance of an item, p2. Low value of $\mathrm{p} 2$ indicate that most of the item variance is explained by the three basic orthogonal factors. h2 measures the variance due to common factors (communality) and $\mathrm{u} 2$ the variance due to unique factor (uniqueness).

\begin{tabular}{|c|c|c|c|c|c|c|c|}
\hline Item & $\mathbf{g}$ & F1* & F2* & $\mathbf{F 3}^{*}$ & h2 & $\mathbf{u} 2$ & p2 \\
\hline PRE_A1 & 0.03 & 0.01 & 0.49 & -0.04 & 0.25 & 0.75 & 0.00 \\
\hline PRE_A5- & 0.02 & -0.09 & -0.20 & -0.20 & 0.09 & 0.91 & 0.00 \\
\hline PRE_A7- & 0.07 & 0.03 & -0.28 & -0.22 & 0.13 & 0.87 & 0.04 \\
\hline PRE_A11 & 0.03 & 0.14 & 0.52 & 0.13 & 0.31 & 0.69 & 0.00 \\
\hline PRE_A22- & 0.04 & 0.14 & -0.49 & 0.02 & 0.26 & 0.74 & 0.00 \\
\hline PRE_A28- & 0.07 & 0.20 & -0.45 & -0.01 & 0.25 & 0.75 & 0.02 \\
\hline PRE_A40- & 0.02 & 0.10 & -0.54 & 0.03 & 0.30 & 0.70 & 0.00 \\
\hline PRE_A50 & 0.05 & 0.11 & 0.52 & 0.03 & 0.28 & 0.72 & 0.01 \\
\hline UT_A4 & 0.14 & 0.36 & 0.10 & 0.03 & 0.16 & 0.84 & 0.12 \\
\hline UT_A16 & 0.25 & 0.60 & 0.17 & -0.04 & 0.45 & 0.55 & 0.14 \\
\hline UT_A17 & 0.21 & 0.52 & 0.08 & 0.00 & 0.33 & 0.67 & 0.14 \\
\hline UT_A18 & 0.21 & 0.54 & -0.09 & 0.02 & 0.34 & 0.66 & 0.13 \\
\hline
\end{tabular}




\begin{tabular}{cccccccc} 
UT_A23 & 0.16 & $\mathbf{0 . 4 3}$ & -0.28 & 0.00 & 0.29 & 0.71 & 0.09 \\
UT_A32 & 0.20 & $\mathbf{0 . 4 8}$ & -0.22 & -0.05 & 0.32 & 0.68 & 0.13 \\
UT_A54 & 0.15 & $\mathbf{0 . 4 3}$ & -0.28 & 0.06 & 0.29 & 0.71 & 0.08 \\
Pro_GMO_A12 & 0.24 & 0.21 & 0.12 & $\mathbf{- 0 . 5 1}$ & 0.38 & 0.62 & 0.15 \\
Anti_GMO_A13- & 0.16 & -0.06 & -0.15 & $\mathbf{- 0 . 6 3}$ & 0.44 & 0.56 & 0.06 \\
& & & & & & & \\
Pro_GMO_A39 & $\mathbf{0 . 3 0}$ & $\mathbf{0 . 3 4}$ & 0.17 & $\mathbf{- 0 . 5 3}$ & 0.52 & 0.48 & 0.17 \\
Anti_GMO_A47- & 0.16 & -0.07 & -0.06 & -0.62 & 0.42 & 0.58 & 0.06 \\
K_GMO_A49- & 0.03 & -0.29 & 0.01 & -0.50 & 0.33 & 0.67 & 0.00 \\
\hline
\end{tabular}

